\title{
Konstruksi Teks Tale Ji Desa Tanjung Pauh Hilir Kerinci-Jambi: Kajian Antropolinguistik
}

\author{
Retmal Karnomo \\ Pendidikan Bahasa Inggris, STKIP-AD
}

\begin{abstract}
Abstrak: Penelitian ini merupakan penelitian deskriptif kualitatif yang bertujuan untuk; (1) Menjelaskan struktur transitivitas teks tale ji, (2) Makna tale ji, dan (3) Fungsi tale ji. Data penelitian yaitu teks tale ji yang didendangkan oleh para penale desa Tanjung Pauh Hilir, Kerinci. Penelitian ini dilakukan melalui tiga tahap, yaitu tahap pengumpulan data, tahap analisis data, dan tahap penyajian hasil analisis data. Pada tahap pengumpulan data, digunakan metode simak. Metode simak tersebut diwujudkan dengan teknik dasar sadap dan teknik lanjutan, teknik rekam bebas libat cakap dan catat. Pada tahap analisis data, digunakan metode padan (translasional, referensial, pragmatik) dan agih (teknik bagi unsur langsung (BUL), Teknik lanjutan teknik lesap dan sisip). Pada tahap penyajian hasil analisis data, digunakan metode formal (tanda dan lambang), serta metode informal (uraian dengan kata-kata biasa). Berdasarkan analisis, ditemukan bahwa: 1) Struktur transitivitas teks tale ji yaitu terdiri dari unsur: a. Proses; material, mental, tingkah, verbal, dan eksistensial. b. Partisipan; tujuan, penyertan, atributif, senser, pelaku, behavier, verbiage, pemilik, pembicara. c. Sirkumstan; cara, tempat, waktu, jarak. Disamping itu, unsur pembentuk struktur teks tale ji yaitu Alaa - alaa ii aa oon dan alaa - la hu allooh yang berfungsi sebagai unsur musikalitas, zikir, dan pembatas antara satu lirik dengan lirik lainnya pada teks tale ji. 2) Makna tale ji adalah makna konseptual, afektif, kolokatif, dan kontekstual. Makna konseptual tale ji yaitu makna tale yang merupakan representasi penerapan konsep agama Islam. Makna afektif tale ji yaitu makna tale yang merupakan representasi kondisi mental antara jamaah calon haji dan masyarakat sekitarnya. Makna kolokatif tale ji yaitu makna tale yang merupakan representasi harapan, doa, dan pesan para penale kapada jamaah calon haji. Makna kontekstual tale ji yaitu representasi kekeluargaan antara masyarakat Desa Tanjung Pauh Hilir. 3) Fungsi tale ji adalah fungsi asertif, direktif, komisif, dan ekspresif.
\end{abstract}

Kata Kunci: Antropolinguistik, Sistemik Fungsional Linguistik, Struktur Transitivitas, Penale, tale ji

\begin{abstract}
This research is qualitave descriptive reserach that aimed to explain; (1) The transitivity structure of text of tale ji, (2) The Meaning of tale ji, and (3) Function of tale ji. The data are the texts of tale ji that uttered by the singers of tale Tanjung Pauh Hilir, Kerinci. This research was done through three steps: data collecting, data analysis, and data presentation. Data collecting is used observational method in which tapping as the basic technique. The advance techniques used nonparticipant observational, recording, and note taking techniques. Data analysis used comparison (translational, referential, pragmatics) and distributional methods (deletion and assertion). The data presentation is formal and informal. Based on analysis, the researcher found that: 1) The structure of transitivity that construct the text of tale ji are: a. Process; material, mental, behavioral, verbal, and existential. b. Participant; goal, carrier, attributive, senser, actor, behavior, verbiage, owner, sayer, and receiver. c. Sirkumstance; manner, place, time. Alaa - alaa ii a oon and alaa - la hu allooh which those functions are as musicallity, dzikir,and the borderer between lyrics of tale ji. 2) The meaning of tale ji are coneptual, affective, collocative, and contextual meaning. Conceptual meaning of tale ji is the representation of Islam teaching aplication. Affective meaning of tale ji is the mental representation between jamaah of hajj and society. Collocative meaning of tale ji is the representation of massages, hopes and praying of penale. Contextual meaning of tale ji is the representation of kinship. 3) The functions of tale ji are assertive, directive, comissive, and ekspressive.
\end{abstract}

Keywords: Anthropolinguistics, Linguistics Functional Sistemic, Transitivity, Penale, Tale ji.

\section{PENDAHULUAN}

Bahasa merupakan bagian dari sistem kebudayaan yang dapat merekam dan merepresentasikan pengalaman hidup masyarakat. Melalui analisis aspek bahasa serta keterkaitannya terhadap sosial budaya, nilai atau pokok suatu teks dapat diketahui secara keseluruhan terutama dalam menjalankan fungsinya sebagai alat interaksi sosial.

Salah satu bagian dari kebudayaan yang diteliti adalah tradisi prosesi sebelum menunaikan ibadah haji yang disebut dengan tale ji. Tradisi tersebut merupakan salah satu wujud dari proses budaya masyarakat Desa Tanjung Pauh Hilir, Kerinci. Fokus penelitan adalah berbasis pada teks tale ji yang didendangkan oleh penale lokal. Teks tale ji dan prosesi mendendangkannya memiliki karakteristik dalam realitas praktis sosial budaya. Penggalan teks tale ji mencerminkan karakteristik unsur internal yang keterpaduannya secara inheren berfungsi dalam interaksi sosial budaya masyarakat.

Secara umum, tujuan penelitian ini adalah untuk memahami dan menjelaskan fenomena praktis kebahasaan masyarakat Desa Tanjung Pauh Hilir yang tercermin pada teks tale ji. Fenomena kebahasaan tersebut dapat ditelusuri keterkaitannya antara aspek internal dan eksternal teks tale ji. Spesifiknya, tujuan dari penelitian ini yaitu Untuk menjelaskan struktur transitivitas, makna dan fungsi teks tale ji Desa Tanjung Pauh Hilir, Kerinci. 
Penelitian ini diharapkan dapat memberikan manfaat, baik secara teoritis maupun praktis. 1) Secara teoritis, manfaat yang dapat diperoleh dari penelitian ini yaitu; (a) Dapat memberikan inspirasi dan motivasi bagi siapapun untuk mengembangkan ilmu yang bersifat interdisipliner, terutama linguistik dan antropologi, (b) Dapat dijadikan referensi perbandingan bagi peneliti lainnya atau yang tertarik untuk mengkaji bahasa dan budaya Kerinci yang tercermin pada teks tale ji Desa Tanjung Pauh Hilir, Kerinci. 2) Secara praktis, (a) Penelitian ini diharapkan dapat dijadikan referensi bagi masyarakat luas dalam memahami bahasa dan budaya masyarakat Desa Tanjung Pauh Hilir, Kerinci. (b) Penelitan ini diharapkan dapat memberikan informasi yang layak dipertimbangkan bagi pembuat kebijakan dalam hal melestarikan kebudayaan daerah.

\section{Landasan Teori}

Pada penelitian ini, peneliti menggunakan beberapa teori sebagai pisau bedah penelitian. Teori - teori yang digunakan yaitu teori antropolinguistik, struktur transitivitas, makna dan fungsi. Peneliti menggunakan defenisi dan konsep teori antropolinguistik Duranti (1997) yang didukung oleh antropolinguist Palmer (1996), Foley (1997) dan Sibarani (2014). Selanjutnya, peneliti menggunakan defenisi dan konsep teori struktur transitivitas M.A.K Halliday (1978, 1985, 2004), Christian M.I.M (2004) dan Eggin.S. (2004). Teori tersebut untuk mempertegas proses analisis representasi budaya masyarakat Desa Tanjung Pauh Hilir Kerinci yang tercermin pada konstruksi teks tale ji. Untuk mengetahui makna yang terkandung dalam konstruksi teks tale ji, peneliti juga menerapkan teori makna menurut Geofrey Leech, Searle (2003) dan Abdul Chaer (2012). Dalam hal ini, peneliti hanya mengambil beberapa klasifikasi makna oleh para tokoh. Kemudian, teori tersebut digunakan untuk menjelaskan makna tale ji berdasarkan rangkaian liriknya yang secara inheren membentuk keterpauan makna teks. Selanjutnya, teori fungsi yang digunakan oleh peneliti adalah teori fungsi tindak tutur yang dikemukakan oleh Searle. Melalui penerapan teori tersebut, peneliti dapat menentukan dan menjelaskan hubungan antara bentuk dan fungsi tuturan para penale yang terdapat pada rangkaian lirik tale ji.

\section{METODE}

Penelitian ini merupakan penelitian deskriptif dengan pendekatan kualitatif. Moleong (1990:6) mengemukakan bahwa penelitian kualitatif adalah penelitian yang bertujuan untuk memahami fenomena tentang apa yang dialami oleh subjek penelitian, seperti perilaku, persepsi, tindakan, dan lain-lain. Nadra dan Reniwati (2009:60) mengemukakan bahwa data merupakan bahan pokok dalam suatu penelitian. Tujuan penelitian adalah untuk menjawab masalah atau pertanyaan yang berhubungan dengan objek sasaran penelitian. Dengan kata lain, dari datalah objek sasaran penelitian itu berada.

Penelitian ini dilakukan melalui tiga tahap, yaitu tahap pengumpulan data, tahap analisis data, dan tahap penyajian hasil analisis data. Pada tahap pengumpulan data, digunakan metode simak. Metode simak tersebut diwujudkan dengan teknik dasar sadap dan teknik lanjutan, teknik rekam bebas libat cakap dan catat. Pada tahap analisis data, digunakan metode padan (translasional, referensial, pragmatik) dan agih (teknik bagi unsur langsung (BUL), Teknik lanjutan teknik lesap dan sisip). Pada tahap penyajian hasil analisis data, digunakan metode formal (tanda dan lambang), serta metode informal (uraian dengan kata-kata biasa).

Sumber data penelitian dapat dikelompokkan ke dalam sumber data substantif dan lokasional. Sudaryanto (1993:63) mengemukakan bahwa sumber data substantif yaitu bahan mentah data yang berbentuk konkrit. Sumber data lokasional yaitu sumber data yang berhubungan dengan asal-muasal data penelitian yang diperoleh oleh peneliti. Sumber data substantif adalah dua buah teks lisan tale ji. Bentuk konkrit data tersebut adalah unsur-unsur lingual atau struktur lingual yang terdapat dalam teks lisan tale ji. Tujuan pemerolehan data substantif tersebut adalah sebagai basis analisis penelitian. Dalam hal ini, teks tale ji dianalisis dari aspek linguistik untuk memperoleh pemahaman dan menjelaskan unsur-unsur lingual atau struktur lingual yang terdapat dalam teks. Data lokasional yaitu Data tersebut diperoleh melalui proses perekaman terhadap para penale lokal Desa Tanjung Pauh Hilir. Waktu dan tempat pengambilan data penelitian yaitu pada malam hari tanggal 19 Agustus 2015 atau hari ketiga Lebaran Idul Fitri 2015 di kediaman salah seorang jamaah calon haji. Selanjutnya, analisis data substantif dilakukan dengan mempertimbangkan konteks teks tale ji. Konteks tersebut diperlukan oleh peneliti untuk memperoleh pemahaman dan menjelaskan korelasi antara struktur lingual yang ada dalam teks tale ji dan konteks sosial budaya masyarakat Desa Tanjung Pauh Hilir.

Instrumen penelitain yang digunakan yaitu sebagai mana yang dinyatakan oleh Moleong dan Sugiyono. Moleong (1990) dan Sugiyono (2012:305) mengemukakan bahwa instrumen penelitian atau alat penelitian dalam penelitian kualitatif adalah peneliti itu sendiri. Peneliti sebagai instrumen utama yang berperan penting dalam analisis dan pengumpulan data. Karakteristik suatu penelitian atau arah dari suatu penelitian ditentukan oleh peneliti itu sendiri tanpa mengabaikan substansi dari objek penelitiannya. Dalam hal ini, peneliti memiliki fungsi untuk menetapkan fokus penelitian, sumber data penelitian, pengumpulan data, analisis data, dan membuat kesimpulan atas temuan 
penelitiannya. Dalam penelitian ini, instrumen pendukung penelitian yang digunakan oleh peneliti adalah teori-teori pendukung, alat rekam berupa handphone, alat tulis, laptop, serta alat cetak elektronik.

Pengumpulan data dilakukan dengan menggunakan metode yang dikemukakan oleh Sudaryanto (1993) dan Mahsun (2005). Metode yang diterapkan yaitu metode simak. Metode simak tersebut diwujudkan dengan teknik dasar sadap. Adapun teknik lanjutan yang diterapkan yaitu teknik rekam bebas libat cakap dan catat. Metode analisis data yang digunakan yaitu metode padan dan metode agih. Metode penyajian hasil analisis data ang digunakan yaitu berupa kaidah-kaidah formal dan informal.

\section{HASIL DAN PEMBAHASAN \\ Struktur Transitivitas Teks Tale Ji \\ Unsur Proses}

Bentuk-bentuk lingual yang berfungsi sebagai proses material yaitu tegek, dimulapeh, rendouk dimungambek, temualah, pegi, diburangkek pulo, pegi, dimulapeh, datangralah dari, diundang, randowk ngaleh, dimunanam, randowklah dikandang, randowk ngaleh, rendowklah dijalan, dapatlah dijalan, rendowk dimunyape, rendowkralah pergi, kaluralah balaek, balaek, janganralah ditingga, dibusuo, tirabing.

Bentuk-bentuk lingual yang berfungsi sebagai proses mental yaitu mulelah, jangeralah sampe dimuningga, doakanlah, tabahkanlah, raso, yang mendayo, dimundoa, mohon maaf, dimuncari, damairalah dapat, dimuncari, damairalah dapat, dimularo, idaklahkan sedih. Bentuk-bentuk lingual yang berfungsi sebagai proses tingkah laku (behavioral) yaitu dengelah, kabur, dengarlah, datangralah, seruralah. Bentuk-bentuk lingual yang berfungsi sebagai proses verbal yaitu dibu-, dibu-, mule, dapatlah dibilang, bilangralah. Bentuk lingual yang berfungsi sebagai proses eksistensial yaitu inehalah.

\section{Unsur Partisipan}

Bentuk-bentuk lingual yang berfungsi sebagai partisipan tujuan (goal) yaitu bismillah, kayo, rukun islam limo, kantay, kamay, bulehalah, dikupado kayo, kepado Allah, supayo, dikupado kayo, dll. Bentuk-bentuk lingual yang berfungsi sebagai partisipan penyerta yaitu dibusamo, anouk jantan, anouk tino, dibusamo-samo, banyaklah cobaan yang, sirempak, serempak pulo, sejalan.

Bentuk-bentuk lingual yang berfungsi sebagai partisipan atributif yaitu hajilah yang mabrur, yang mabrur, idak dibutepi, idak dibubatih, anouk jantan, anouk tino. Bentuk-bentuk lingual yang berfungsi sebagai partisipan senser: hati, kayo, atay, hatilah. Bentuk-bentuk lingual yang berfungsi sebagai partisipan pelaku (actor) yaitu kamay, kayo, iblis, kayo. Bentuk-bentuk lingual yang berfungsi sebagai partisipan behavior yaitu asaplahnyo, rangan, gunung, wahai tanowh mekah. Bentuk-bentuk lingual yang berfungsi sebagai partisipan verbiage yaitu tale, ngato, pesan, naeklah sereban, ranyo limolah dan limo.

Bentuk-bentuk lingual yang berfungsi sebagai partisipan pemilik yaitu kamay, sudaro kamay, darilahnyo kamay, siapo. Bentuk lingual yang berfungsi sebagai partisipan pembicara (sayer) yaitu Kamay. Bentuk lingual yang berfungsi sebagai partisipan carrier yaitu kayo. Bentuk-bentuk lingual yang berfungsi sebagai partisipan penerima (receiver) yaitu kamaylah, sodaro.

\section{Unsur sirkumstan}

Bentuk-bentuk lingual yang berfungsi sebagai sirkumstan cara yaitu kalu, nian denganlahnyo bilah, kalu, nian. Bentuk-bentuk lingual yang berfungsi sebagai sirkumstan tempat yaitu diku makah, tibulah di makah, pundowklah siguang, makah dan mudinah, diku sawah nian, diku makah nian, tanjung tanah. Bentuk-bentuk lingual yang berfungsi sebagai sirkumstan waktu yaitu bilu, cukuplah sekian, jaranglah, bilu dibusuo. Bentuk-bentuk lingual yang berfungsi sebagai sirkumstan jarak yaitu sungguhralah dekat, tinggay.

\section{Makna Tale Ji}

Makna tale ji yaitu makna konseptual, afektif, kolokatif, dan kontekstual. Makna konseptual tale ji adalah representasi ideologi agama Islam dalam prosesi tale ji. Makna afektif tale ji adalah representasi ekspresi pertemuan atau perpisahan antara masyarakat dan para jamaah calon haji yang akan menunaikan ibadah haji ke Mekah.

Makna kolokatif tale $j i$ adalah representasi suatu realitas tantangan atau cobaan yang akan dialami oleh para jamaah calon haji dalam menjalankan ibadah haji di Mekah. Makna kontekstual tale ji adalah representasi hubungan kekeluargaan antara anggota masyarakat desa Tanjung Pauh Hilir Kerinci. Hal tersebut tercermin banyaknya anggota masyarakat yang terlibat pada prosesi tale ji. Selanjutnya, representasi kekeluargaan tersebut juga tercermin melalui isi tale ji berupa pesan dan doa dari para penale. 


\section{Fungsi Tale Ji}

Fungsi tale ji adalah fungsi asertif, komisif, dan ekspresif. Fungsi asertif tale ji yaitu pernyataan para penale yang berhubungan dengan kondisi atau aktivitas saat tale mulai didendangkan dan diakhiri. Fungsi direktif tale ji yaitu representasi ajakan dan permohonan izin penale kepada jamaah calon haji beserta keluarganya untuk memulai tale ji.

Fungsi komisif tale $j i$ adalah fungsi lirik tale yang berkaitan dengan isi permohonan atau pesan yang disampaikan oleh para penale kepada jamaah calon haji. Pesan-pesan tersebut diperlukan tindakan lebih lanjut dari para jamaah calon haji. Fungsi ekpresif tale ji yaitu berkaitan dengan representasi permohonan maaf para penale (tokoh masyarakat) kepada jamaah calon haji jika terdapat perkataan atau sikap mereka yang kurang berkenan. Serta, fungsi ekspresif tale ji yaitu representasi ekspresi perpisahan dan pertemuan antara para jamaah calon haji dan masyarakat sekitarnya.

\section{SIMPULAN}

Pada konteks budaya, wujud praktis bahasa pada teks tale ji merupakan tuturan yang berfungsi dan bermakna bagi masyarakat Desa Tanjung Pauh Hilir Kerinci, Jambi. Teks tale ji dan prosesi mendendangkannya memiliki karakteristik dalam realitas praktis sosial budaya. Konstruksi lingual yang digunakan oleh para penale merupakan cerminan kebudayaan masyarakat Desa Tanjung Pauh Hilir Kerinci yang terikat dengan nilai sosial budaya daerahnya. Dalam hal ini, tale ji bukan hanya sekadar alat komunikasi semata tetapi juga sebagai alat penyampaian nilai-nilai sosial budaya yang dianut oleh masyarakat.

Ada beberapa hal yang dapat peneliti ajukan sebagai saran yang berhubugan dengan penelitian ini, yaitu; 1) Penelitian ini hanya mencakup bentuk-bentuk lingual struktur transitivitas, makna dan fungsi teks tale ji. Oleh karena itu, penelitian tentang tale perlu pengkajian lebih lanjut, baik pada tataran fonologi, morfologi maupun sintaksis, terutama yang berkaitan dengan representasi budaya Kerinci yang tercermin pada teks tale. 2) Penelitian ini hanya terbatas pada teks tale ji Desa Tanjung Pauh Hilir saja. Oleh karena itu, diharapkan kepada peneliti berikutnya untuk dapat melanjutkan atau mengembangkan penelitian ini pada teks tale ji di berbagai dearah Kerinci lainnya sebagai perbandingan penelitian. Sehingga penelitian tersebut dapat memberikan kontribusi atau menambah khasanah data kajian ilmu antropolinguistik terutama yang berkaitan dengan realitas praktis bahasa di berbagai daerah Kabupaten Kerinci.

\section{DAFTAR PUSTAKA}

Chaer, Abdul. 2012. Linguistik Umum:Edisi Revisi. Jakarta:Rineka Cipta.

Duranti, Alessandro. 2000. Linguistics Anthropology. University Press: Cambridge.

Duranti, Alessandro. 2001. Linguistic Anthropology. Massachusetts:Blacwell.

Duranti, Alessandro. 2004. A Companion to Linguistics Antropology. Maldan:Balckwell.

Eggin.S. 2004. An Introduction to Systemic Functional Linguistics. London:Printer.

Foley,W.A. 1997. Anthropological Linguistics:An Introduction. Oxford:Blackwell.

Halliday, M.A.K. 1978. Language as Social Semiotic:The Social Interpretation of Language and Meaning. London:Edward Arnold.

Halliday, M.A. K. dan R. Hasan. 1985. Language Context, and text:Aspect of language in a social semiotic Perspective. London:Oxford University Press.

Halliday, M.A. K. dan Christian M.I.M. 2004. An Introduction to Functional Grammar:Fourth Edition. New York:Routledge.

Mahsun. 2005. Metode Penelitian Bahasa. Jakarta:PT Raja Grafindo Persada.

Moleong, L. J. 1990. Metodologi Penelitian Kualitatif. Bandung:PT. Remaja Rosdakarya.

Palmer, Gary B. 1996. Toward A Theory Of Cultural Linguistics. USA:The University of Texas Press.

Sibarani, $\quad$ Robert.2004. Antropolinguistik:Antropologi Linguistik dan Linguistik Antropologi. Medan:Penerbit Poda.

Sudaryanto. 1990. Menguak Fungsi Hakiki Bahasa. Yogyakarta:Duta Wacana University Press.

Sudaryanto. 1993. Metode dan Aneka Teknik Analisis Bahasa. Yogyakarta:Duta Wacana University Press.

Sugiyono. 2009. Memahami Penelitian Kualitatif. Bandung: Alfebeta.

Sugiyono. 2012. Metode Penelitian Pendidikan; Pendekatan Kuantitatif, Kualitatif, dan R\&D. Bandung:Alfabeta. 